\title{
Effects of activating flux on aluminum alloy to steel butt-joint using a MIG weld-brazing process
}

\author{
Hsuan-Liang LIN*, Fu-Jyun NAN* and You-Jiun WANG* \\ ${ }^{*}$ Department of Industry Technology Education, National Kaohsiung Normal University \\ Yanchao, Kaohsiung 82444, Taiwan \\ E-mail: hllin@nknu.edu.tw
}

Received: 19 April 2021; Revised: 17 August 2021; Accepted: 11 October 2021

\begin{abstract}
A novel metal inert gas (MIG) weld-brazing was employed to produce the dissimilar materials butt-joint welds that specimens consisted of 6061 aluminum (Al) alloy and galvanized steel sheet. In this process, the fluxes such as $\mathrm{CaF}_{2}, \mathrm{TiO}_{2}, \mathrm{SiO}_{2}$ and $\mathrm{ZnO}$ powder were coated on the surface of steel respectively to investigate the effect of activating fluxes on the performance of specimens. The experimental results revealed that $\mathrm{CaF}_{2}$ flux powder was applied as a suitable flux which spreadability of filler material on steel surface become better. In order to obtain better appearances of specimen surface, the coating thickness of flux powder should be accurately control at 0.1 $\mathrm{mm}$. When $\mathrm{SiO}_{2}$ flux powder was coated on surface of specimen, the amount and the size of porosity decrease simultaneously in the fusion zone (FZ) of weld bead. It led to improve the tensile strength of Al/steel butt-joint specimens. The surface of specimens coating with $\mathrm{CaF}_{2}, \mathrm{TiO}_{2}$ or $\mathrm{SiO}_{2}$ flux powder, the thicknesses of intermetallic compound (IMC) layer were less than $10 \mu \mathrm{m}$. The specimens produced by coating with $\mathrm{ZnO}$ flux may increase the temperature of FZ, the average thickness of IMC layer was $14.62 \mu \mathrm{m}$ and the IMC layer presents a saw tooth shape.
\end{abstract}

Keywords : Metal inert gas (MIG) welding, Brazing, Activating flux, Aluminum, Galvanized steel

\section{Introduction}

Compared with the low-carbon steel sheet, use of Al alloys as automotive parts has many advantages such as higher weight-strength ratio and recoverability. The reduction of fuel utilization could be accomplished by using light materials such as Al panels and body frame of the vehicles. The vehicle structures adopt Al alloys that could lead to weight reduction and energy saving. Due to the outstanding resist of corrosion, the galvanized steel sheet has been extensively employed by the automotive industry as well. The dissimilar materials joining performance of Al alloy and galvanized steel sheet has been paid growing attention in manufacturing industries (Zhang et al. 2013). The brittle intermetallic compounds (IMCs) are formed between the interface of $\mathrm{Al}$ and steel during welding process, it is difficult to achieve a proper joint of Al/steel by means of the traditional arc welding process (Lin et al. 2018). Therefore, Chen et al. (2019) utilized the friction stir welding process to produce the lap joints of $6061 \mathrm{Al}$ alloy and steel sheet. When the welding parameters were set at optimal conditions, the maximum failure load of specimen was achieved at $2.26 \mathrm{kN}$. Dong et al. (2016) employed the refilled friction stir spot welding process to produce the lap joints of $\mathrm{Al}$ alloy and steel sheet. When the welding parameters were set at optimal conditions, the maximum tensile-shear fracture load of specimen was achieved at $3.044 \mathrm{kN}$. All of the tensile-shear testing specimens failed at the interface between $\mathrm{Al}$ and steel. Lü et al. (2018) used the laser fusion weld-brazing process to produce the lap joints of $\mathrm{Al} / \mathrm{steel}$. When the welding parameters were set at optimal conditions, the maximum tensile fracture load of specimen was achieved at $152.5 \mathrm{MPa}$. Wider lap interface between $\mathrm{Al}$ and steel, and narrow heat affect zone (HAZ) were formed by employing this laser weld-brazing process. However, these novel weld-brazing processes have disadvantage of either lacking versatility or high cost.

The MIG weld-brazing process has been recommended to obtain higher quality of joints between $\mathrm{Al}$ and steel that using appropriate heat input to melt Al alloy but maintain the steel in solid state. Shao et al. (2015) adopted a pulsed double electrode MIG welding process to generate the joint of $\mathrm{Al} /$ steel. The low heat input was used to the specimen that 
was finalized by varying the bypass current in this novel welding process. When the heat input reduced, the amount of IMC phases gradually decreased. Ye et al. (2017) employed the MIG-TIG double-sided arc welding process to generate butt joint of $\mathrm{Al} /$ steel. When the MIG voltage enhances, the thickness of IMC layer increases at the interface between $\mathrm{Al}$ and steel. The appearance of weld bead and interface between $\mathrm{Al}$ and steel significantly impact the tensile strength of the $\mathrm{Al} /$ steel butt-joint welds, and the tensile strength of specimen was achieved at $150 \mathrm{MPa}$ in this process. Basak et al. (2016) used a pulsed MIG weld-brazing process to produce the lap-joint of $\mathrm{Al} / \mathrm{steel}$. When the welding parameters were set at optimal conditions, the maximum tensile fracture load of specimen was achieved at $243 \mathrm{MPa}$. Due to the surface protection, $\mathrm{Zn}$ coating is necessary for $\mathrm{Al}$ alloy and steel joining, the metallic characteristic after evaporation of $\mathrm{Zn}$ rather than the oxidic characteristic for un-galvanized steel.

Based on the above research, $\mathrm{Zn}$ is an unstable factor that needs to be avoided by a reasonable design in the weldbrazing process (Lin et al. 2016). Therefore, Qin et al. (2017) developed a fluoride flux that coated on surface of steel may improve the spreadability of filler materials. The fluoride flux floating on the surface of welding pool that weakened the surface tension in the FZ and then reduced the evaporation of $\mathrm{Zn}$. It led to enhance the mechanical property of the dissimilar materials butt-joint welds greatly. When the activating flux was set at optimal component, the maximum tensile fracture load of specimen was achieved at $120 \mathrm{MPa}$. Goecke et al. (2019) demonstrated that increase the MIG welding heat input, the porosity in FZ reduce. It attributed to efficient escape of Zn-vapor from the molten bead deposit between $\mathrm{Al}$ and steel. When the welding heat input was set at optimal conditions, the maximum tensile fracture load of specimen was achieved at $1.82 \mathrm{kN}$. In additions, Huang et al. (2007) investigated the effects of arc constriction on the penetration of welds, the $\mathrm{SiO}_{2}$ flux powder was coated on the surface of $\mathrm{Al}$ base metal. The experimental results demonstrated that $\mathrm{SiO}_{2}$ flux powder was coated on the surface of $\mathrm{Al}$ base metal could make the welding arc to be constricted. Therefore, it led to the high melting temperature and boiling temperature resistively in fusion zone of the process. Based on above technical literature, the object of this work is to investigate the effects of fluxes such as $\mathrm{CaF}_{2}, \mathrm{TiO}_{2}, \mathrm{SiO}_{2}$ and $\mathrm{ZnO}$ powder on appearance of specimen surface and microstructure of weld bead, porosity of FZ, IMC layer of interface and mechanical property of specimens during MIG weld-brazing process.

\section{Materials and experimental procedure}

In this MIG weld-brazing process, $6061 \mathrm{Al}$ alloy and galvanized steel sheets were selected as base metals. The dimensions of Al alloy and galvanized steel sheets were $180 \mathrm{~mm} \times 50 \mathrm{~mm} \times 3.0 \mathrm{~mm}$ and $180 \mathrm{~mm} \times 70 \mathrm{~mm} \times 1.2 \mathrm{~mm}$, respectively. The diameter $1.6 \mathrm{~mm}$ ER4043 filler wire was chosen as the filler material. The chemical composition of $\mathrm{Al}$ alloy, steel sheet and filler material are listed in Table 1.

Table 1. Chemical content of base metals and filler material

\begin{tabular}{|l|c|c|c|c|c|c|c|c|c|c|c|c|}
\hline Components, Wt. \% & $\mathrm{C}$ & $\mathrm{Si}$ & $\mathrm{Mn}$ & $\mathrm{P}$ & $\mathrm{S}$ & $\mathrm{Fe}$ & $\mathrm{Zn}$ & $\mathrm{Mg}$ & $\mathrm{Cu}$ & $\mathrm{Cr}$ & $\mathrm{Ti}$ & $\mathrm{Al}$ \\
\hline Galvanized steel & 0.02 & 0.01 & 0.18 & 0.03 & 0.01 & $\mathrm{Bal}$ & - & - & - & - & - & - \\
\hline 6061 Aluminum & - & 0.6 & 0.15 & - & - & 0.7 & 0.25 & 1.2 & 0.15 & 0.25 & 0.15 & Bal. \\
\hline 4043 filler wire & - & 5 & 0.05 & - & - & 0.8 & 0.1 & 0.05 & 0.3 & - & 0.2 & Bal. \\
\hline
\end{tabular}

The experimental procedure that produce a butt-joint specimen consist of $6061 \mathrm{Al}$ alloy and steel sheet, the root opening between $\mathrm{Al}$ alloy and steel sheet was fixed at $0.4 \mathrm{~mm}$. Before the process, the oxide layer on the surfaces of 6061 Al alloy plate was polished by using a sanding machine. In additions, the flux powders that selected by the authors were mixed with methanol $\left(\mathrm{CH}_{3} \mathrm{OH}\right)$ to produce a paint-like consistency, as shown in Fig.1a and 1b. Four single-component activating fluxes such as $\mathrm{CaF}_{2}, \mathrm{TiO}_{2}, \mathrm{SiO}_{2}$ and $\mathrm{ZnO}$ powder were coated on the surface of galvanized steel sheet using a brush, respectively. As shown in the Fig.1c, four types of activating flux powder were coated on the surface of galvanized steel sheet. In the experiment of this study, the thickness of activating flux powder was accurately control at 0.1 and 0.3 $\mathrm{mm}$ by mean of using different proportion solute between methanol and activating flux powder. The MIG welding machine (Horbart Mega-Pluse MPI-350) and the welding torch can be set at different speeds was utilized to produce a butt-joint specimen. The travel speed of MIG torch was set at $270 \mathrm{~mm} / \mathrm{min}$, and the MIG welding voltage and the feed of filler wire were set at $17 \mathrm{~V}$ and $91 \mathrm{~mm} / \mathrm{sec}$ respectively. Based on these MIG welding parameters, the welding current 
was regulated between 18 and 21A during the MIG arc brazing process which using different activating flux powder. This study utilized argon (Ar) as the shielding gas and the flow rate was set at $17.5 \mathrm{~L} / \mathrm{min}$. After MIG weld-brazing process, three tensile strength testing specimens with $10 \mathrm{~mm}$-wide were cut from each dissimilar materials butt-joint weld. The surface condition of specimens, cross-section, microstructure and porosity of weld bead, the thickness of IMC layer in the FZ were investigated by the optical microscope (OM) and scanning electron microscope (SEM).

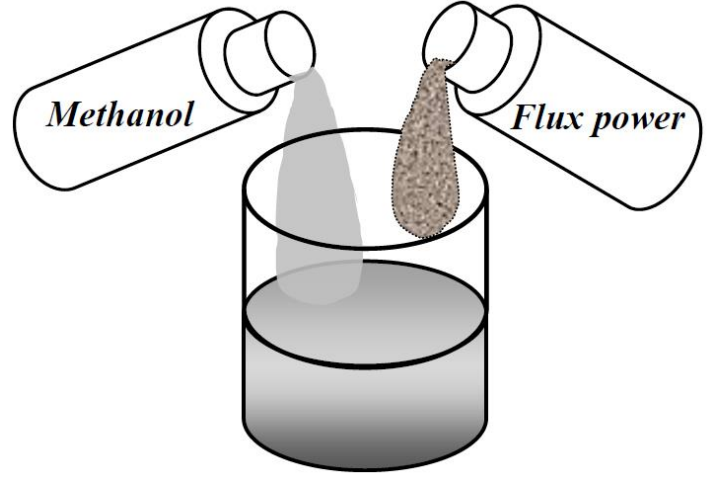

a. Mixing flux powder with methanol

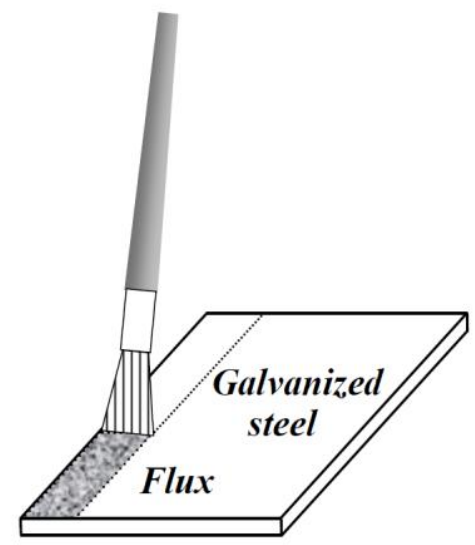

b. Coating flux using a brush

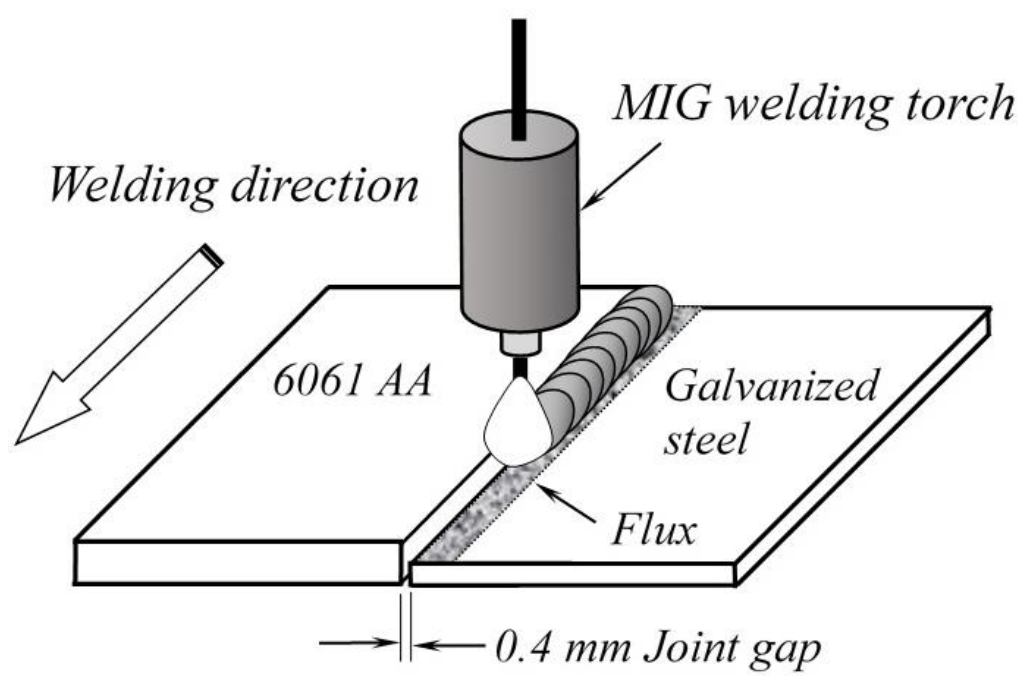

c. MIG weld-brazing process using the activating flux

Fig. 1 Schematic diagram of coating method and MIG weld-brazing process using the activating flux.

\section{Results and discussions}

\subsection{Effect of flux thickness on surface of specimens}

The appearances of specimen surface that four types of activating flux powder were coated with 0.3 mm thickness on the surface of steel sheet as shown in Fig. 2. The specimens that coated with $\mathrm{CaF}_{2}, \mathrm{TiO}_{2}, \mathrm{SiO}_{2}$ and $\mathrm{ZnO}$ powder, the weld beads of specimen surface are incomplete and numerous spatters. This is in accord with the research that implemented by the author in the previous experimental results (Lin et al. 2014 and Lin 2017). It demonstrated that the

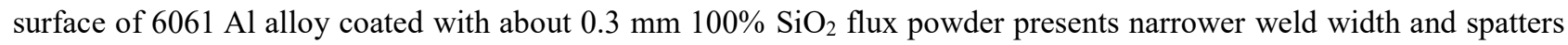
because of high melting temperature and arc constriction on the top of MIG weld pool. Therefore, the specimen that coated with $\mathrm{SiO}_{2}$ flux powder presents narrower weld width and many spatters as shown in Fig. 2c.

Qin et al. (2017) demonstrated that a modified flux consists from $73.6 \mathrm{wt} . \% \mathrm{KAlF}_{4}+18.4$ wt.\% $\mathrm{K}_{3} \mathrm{AlF}_{6}+8 \mathrm{wt} . \%$ $\mathrm{K}_{2} \mathrm{SiF}_{6}$, which floats on the weld pool surface and $\mathrm{Zn}$ is avoided to be directly heated by the MIG arc. It led to that the evaporation of $\mathrm{Zn}$ is decreased and liquid Al filler material can spread on the surface of steel well, the joint strength can 
reach up to $120 \mathrm{MPa}$. Qin et al. (2017) showed that the specimen coated with $100 \mathrm{wt} \% \mathrm{KAlF}_{4}$ flux had the best spreadability of filler metal, the width of Al alloy weld bead was $6.6 \mathrm{~mm}$ approximately. As shown in Fig. 3, the specimen surface that four types of activating flux powder were coated with $0.1 \mathrm{~mm}$ thickness on the surface of steel. The specimens coated with thin layer of flux powder, the appearances of weld bead are complete and very few spatters, the width of Al alloy weld bead is $6.5 \mathrm{~mm}$ approximately. This experimental results revealed that the outcome of specimens coating with $\mathrm{CaF}_{2}, \mathrm{TiO}_{2}, \mathrm{SiO}_{2}$ or $\mathrm{ZnO}$ powder were similar to that coated with a modified flux developed by the Qin et al. (2017). In order to obtain higher quality of $\mathrm{Al} /$ steel dissimilar materials butt-joint welds, the thickness of activating flux should be accurately control.
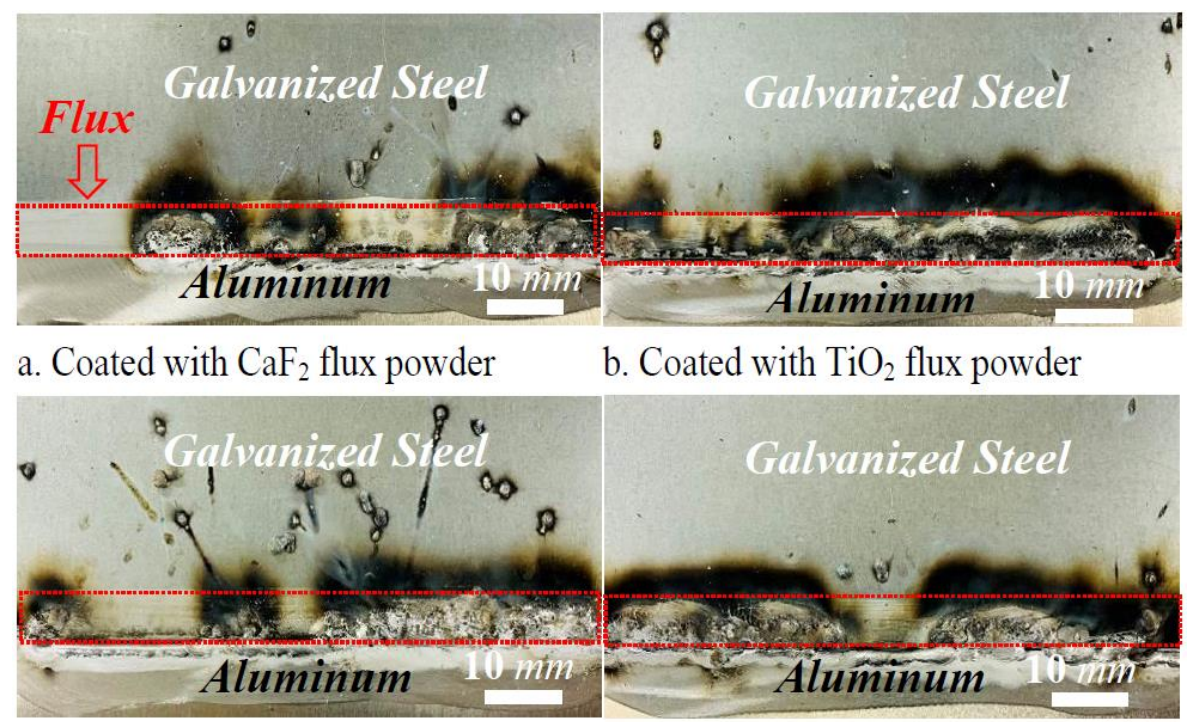

c. Coated with $\mathrm{SiO}_{2}$ flux powder d. Coated with $\mathrm{ZnO}$ flux powder

Fig. 2 The appearances of specimen surface coated with $0.3 \mathrm{~mm}$ flux powder.
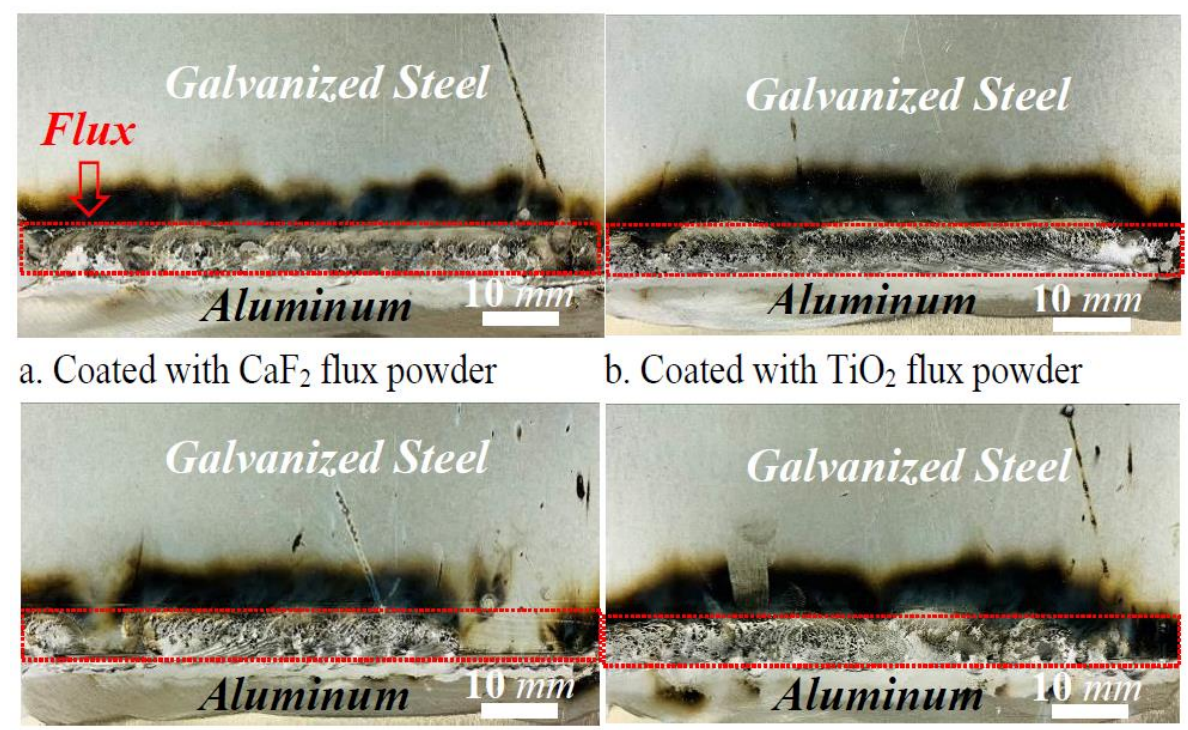

c. Coated with $\mathrm{SiO}_{2}$ flux powder $\quad$ d. Coated with $\mathrm{ZnO}$ flux powder

Fig. 3 The appearances of specimen surface coated with $0.1 \mathrm{~mm}$ flux powder.

\subsection{Effect of flux on spreadability of weld bead}

Fig.4 shows the variations of the FZ and weld bead (WB) geometry that the surface of galvanized steel sheet coated with $0.1 \mathrm{~mm}$ thickness of $\mathrm{CaF}_{2}$ and $\mathrm{SiO}_{2}$ flux powder. The thickness of $\mathrm{Al}$ alloy and galvanized steel base metal (BM) were $3 \mathrm{~mm}$ and $1.2 \mathrm{~mm}$, respectively. As shown in Fig. 4a, the OM images reveal that the $\mathrm{CaF}_{2}$ flux powder was applied 
as a suitable flux for the dissimilar materials butt-joint welds. Qin et al. (2017) showed that both the spreadability of filler material on galvanized steel surface and the weld appearance become better after specimens coating with $\mathrm{KAlF}_{4}$ flux powder. The experimental results revealed that the fluoride powder was suggested to examine an activating flux for buttjoint of $\mathrm{Al}$ /steel butt-joint. In summary, the outcome of specimens coating with $\mathrm{CaF}_{2}$ powder was similar to that coated with $\mathrm{KAlF}_{4}$ flux powder developed by the Qin et al. (2017). the dissimilar materials butt-joint welds that produced by coating with $\mathrm{SiO}_{2}$ flux powder appears the deeper penetration in the $\mathrm{FZ}$ of weld bead. In a previous research (Lin et al. 2017) developed by the author, the Marangoni convection has been proposed to explain the mechanism that increases the penetration of MIG welds produced by coating with $\mathrm{SiO}_{2}$ flux powder on the surface of Al alloy base metal. The Marangoni convection could explain the deeper penetration of weld bead that specimen produced by coating with $\mathrm{SiO}_{2}$ flux powder. However, it may decrease spreadability of filler material on the steel surface during MIG weld-brazing.

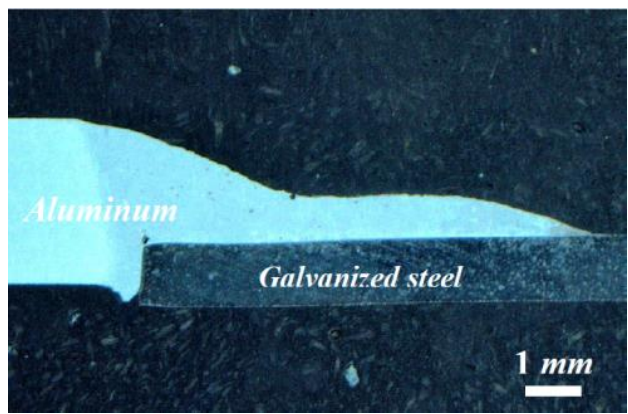

a. Coated with $\mathrm{CaF}_{2}$ flux powder

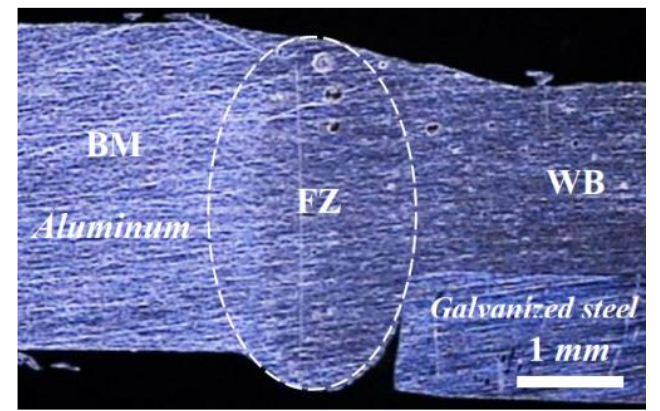

b. Coated with $\mathrm{SiO}_{2}$ flux powder

Fig. 4 The cross-section of welds coated with $\mathrm{CaF}_{2}$ and $\mathrm{SiO}_{2}$ flux powder.

\subsection{Effect of flux on microstructure of fusion zone}

Ruan et al. (2012) revealed that the penetration of welds produced by employing a twin wire MIG welding process using $\mathrm{SiO}_{2}$ flux powder was about $26 \%$ deeper than that of the welds prepared without any activating flux. The arc constriction and higher arc temperature were the main reasons for increased penetration. Due to the higher arc temperature, the grain size of specimens coated with $\mathrm{SiO}_{2}$ flux coarser than that of the welds prepared without any activating flux. In additions, it demonstrated that the specimens coated with $\mathrm{SiO}_{2}$ flux powder did not have obvious effect on the mechanical properties of Al alloy welds.

The microstructure of FZ that the specimens coated with $\mathrm{SiO}_{2}$ flux powder and without activating flux is shown in Fig.5. Generally, the FZ that specimens produced by employing $4043 \mathrm{Al}-\mathrm{Si}$ filler wires was consisted of short rod-like Al-Si eutectics in grain boundaries and $\alpha$-Al solid solution dendrites (Dong et al. 2012). The $\alpha$-Al solid solution of FZ made with 4043 filler wire that includes very few Al-Si eutectics in the entire welds as shown in Fig.5. In additions, a columnar crystal zone around the $\mathrm{FZ}$ is similar to the specimens that produced by $\mathrm{SiO}_{2}$ flux powder and without activating flux on the surface of galvanized steel sheet. When $\mathrm{SiO}_{2}$ flux powder was coated, the grains were coarser obviously than others as shown in Fig. 5b. The results are similar to the specimens that produced by Ruan et al. (2012).

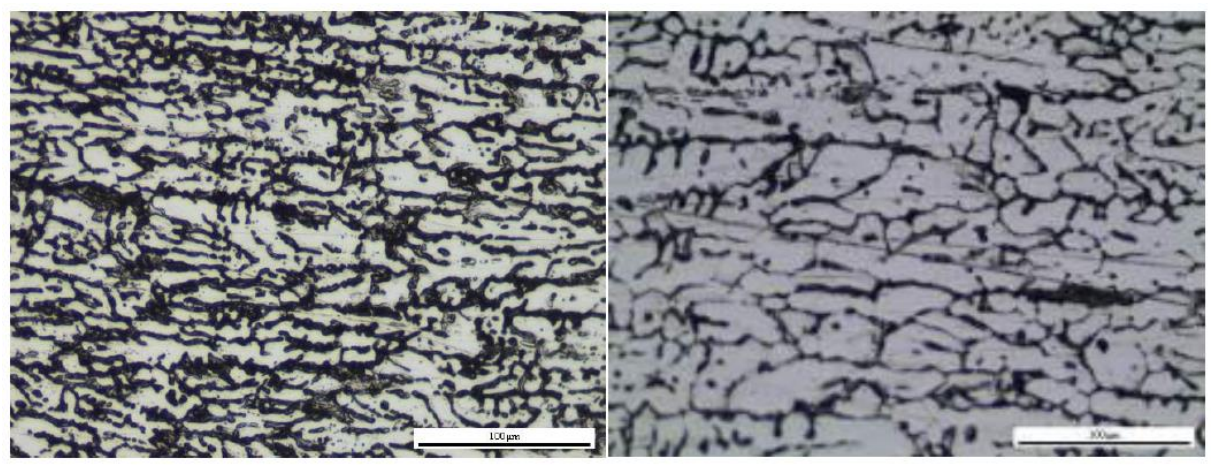

\section{a. Without coated flux powder b. Coated with $\mathrm{SiO}_{2}$ flux powder}

Fig. 5 Effect of activating flux on microstructure of weld bead. 


\subsection{Effect of flux on tensile strength of specimens}

The tensile strength of specimens that produced by traditional process without coated with flux and coated with $\mathrm{CaF}_{2}, \mathrm{TiO}_{2}, \mathrm{SiO}_{2}$ and $\mathrm{ZnO}$ flux powder under the same MIG weld-brazing conditions were obtained as shown in Fig.6. For each activating flux powder, three sampling specimens were used to estimate the tensile strength of welds. Compare with the specimens coated with activating flux, the average tensile strength of welds that specimens coated with the four types flux powder selected by authors were better than that without coating any flux powder. The experimental results indicated that the traditional MIG weld-brazing process without use of activating flux, the average tensile strength of welds was 107.3 MPa. However, the surface of galvanized steel sheet coated with $\mathrm{CaF}_{2}, \mathrm{TiO}_{2}, \mathrm{SiO}_{2}$ and $\mathrm{ZnO}$ flux powder, the average tensile strength of welds was $137.8,128.6,160.6$ and $130.3 \mathrm{MPa}$, respectively. The tensile strength of specimens that coated with activating flux powder was measured higher than 107.3 MPa. When the surface of galvanized steel sheets coated with $\mathrm{SiO}_{2}$ flux powder, the dissimilar materials butt-joint weld has the highest tensile strength. During the tensile testing process, all specimens fractured through the $\mathrm{FZ}$ of dissimilar materials butt-joint welds. It demonstrated that the four types flux powder were coated on the surface of steel with $0.1 \mathrm{~mm}$ thickness could improve the tensile strength of welds. Based on the comparison of the results as shown in Fig.6 and the microstructure of fusion zone as shown in Fig.5, it was found that the grain size of FZ is not a main factor that affect the tensile strength of specimens in this study.

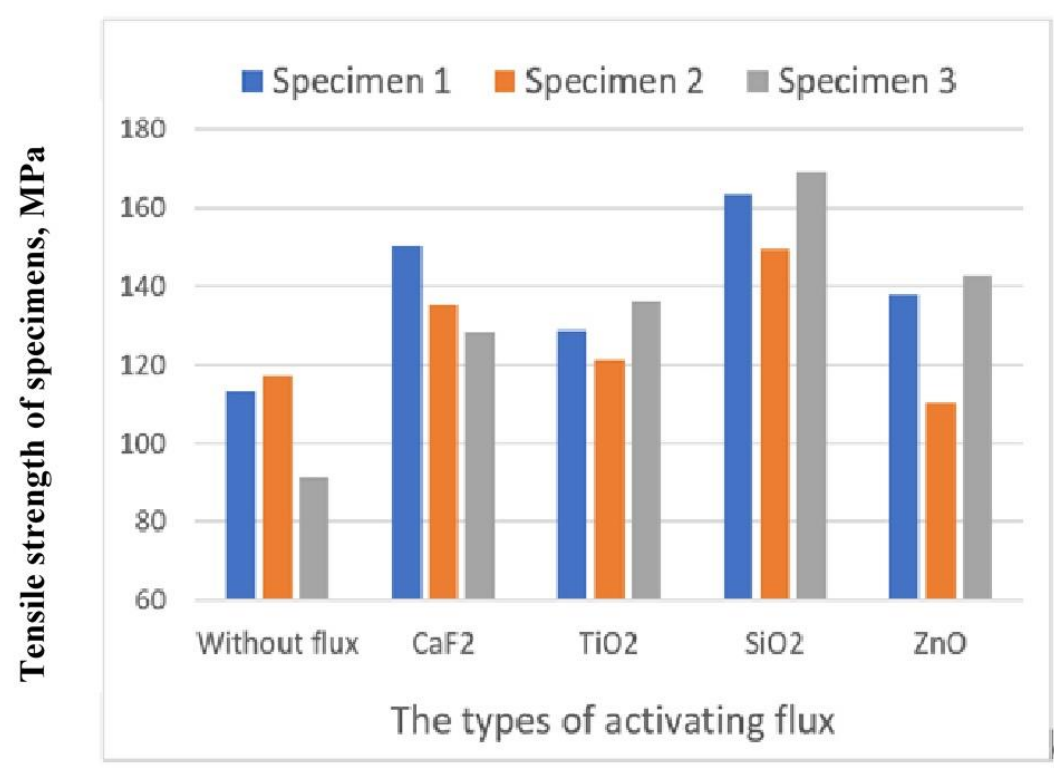

Fig. 6 Tensile strength of specimens produced by coating flux.

\subsection{Effect of flux on porosity in the fusion zone}

The fractured surfaces for the tensile strength testing specimens at 40 magnifications are shown in Fig. 7. The amount of porosities that specimen produced by coating with $\mathrm{CaF}_{2}$ and $\mathrm{SiO}_{2}$ flux powder are less than $\mathrm{TiO}_{2}$ and $\mathrm{ZnO}$. It demonstrated that the tensile strength of specimen produced by coating with $\mathrm{CaF}_{2}$ and $\mathrm{SiO}_{2}$ flux powder higher than the others. Goecke et al. (2019) showed that the porosity in the FZ reduce with increase the welding heat input. It attributed to efficient escape of $\mathrm{Zn}$-vapor from the molten bead deposit. Due to the higher arc temperature [15], the grain size of specimens that coated with $\mathrm{SiO}_{2}$ flux coarser than that of the specimens produced without any activating flux as shown in Fig.5. As shown in Fig.6, the surface of steel sheet coating with the four types of flux powder, the average tensile strength of specimens improves. The tensile strength of specimens that the surface of steel sheet coated with $\mathrm{SiO}_{2}$ flux powder is the highest. In summary, the tensile strength of aluminum alloy to steel butt-joint specimens attributed to the amount and size of porosity in the FZ. The fractured surfaces of specimens that executed the tensile strength testing are shown in Fig. 7. Due to the fracture occurred in the FZ that consist of $6061 \mathrm{Al}$ alloy and 4043 filler material, the fractured surfaces were represented with dimple semblance that illustrated the ductile fracture. Many of porosities appear on fractured surfaces that belongs to the $\mathrm{FZ}$ of weld bead. When the surface of galvanized steel sheet coating with the $\mathrm{CaF}_{2}$, $\mathrm{TiO}_{2}$ or $\mathrm{ZnO}$ flux powder, specimens increase the amount of porosity in the $\mathrm{FZ}$, which contain about $15 \%, 23 \%$ and 20 
\% porosities of FZ respectively as shown in Fig. $8 \mathrm{a}, 8 \mathrm{~b}$ and $8 \mathrm{~d}$. It decreases the tensile strength of the Al/steel butt-joint specimens as shown in Fig.6. When the surface of galvanized steel sheet coating with the $\mathrm{SiO}_{2}$ flux powder, the heat inputs cause efficient escape of Zn-vapor from the molten bead deposit, specimen decreases the amount and size of porosity, which contain only $3 \%$ porosities of FZ as shown in Fig.8c. Therefore, the tensile strength of the Al/steel buttjoint specimens improves.
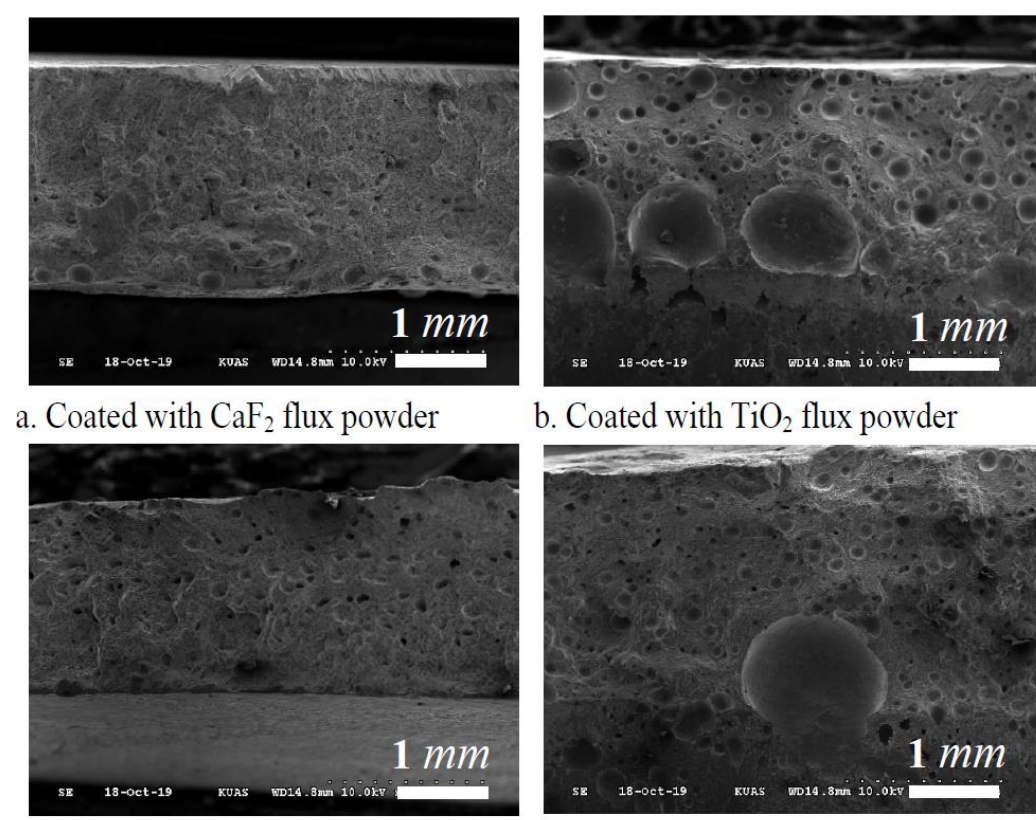

c. Coated with $\mathrm{SiO}_{2}$ flux powder

d. Coated with $\mathrm{ZnO}$ flux powder

Fig. 7 Fracture surface of specimens at 40 magnifications.
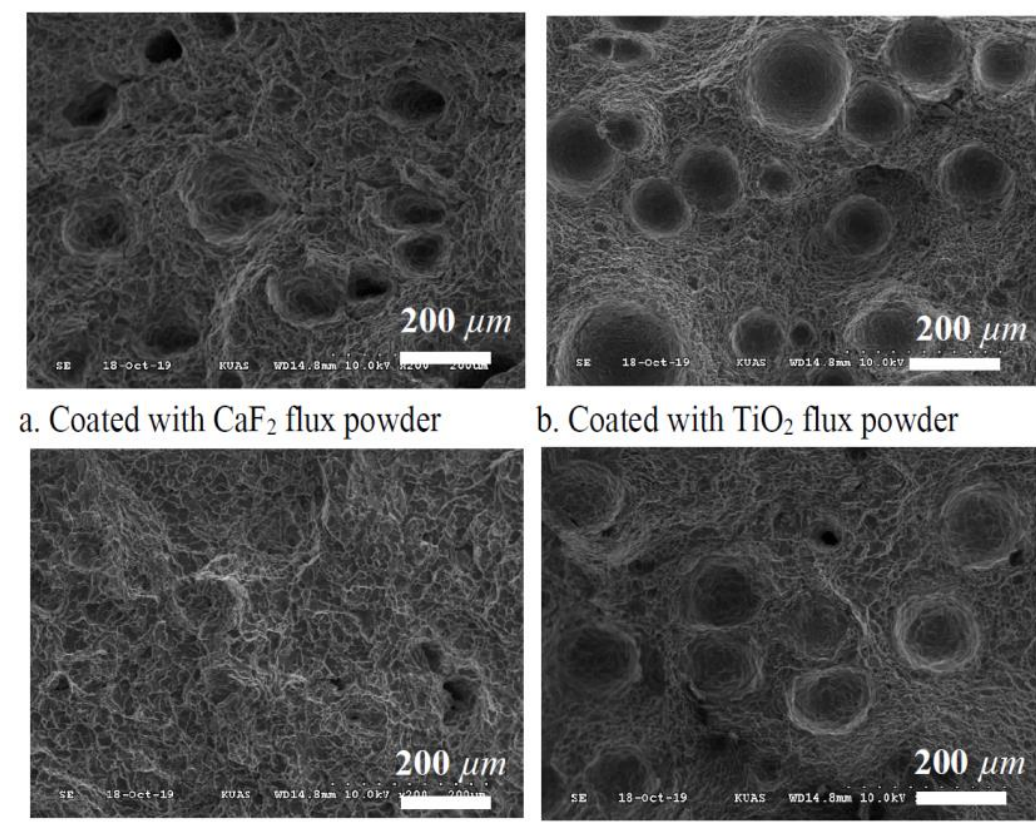

b. Coated with $\mathrm{TiO}_{2}$ flux powder

c. Coated with $\mathrm{SiO}_{2}$ flux powder

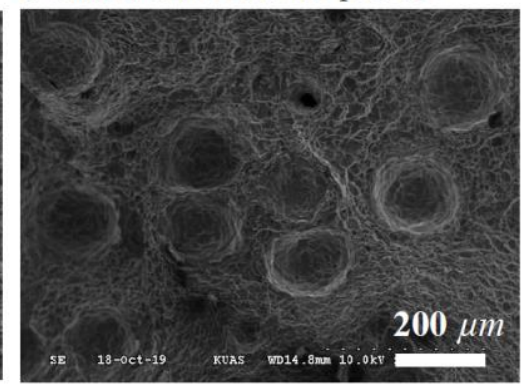

d. Coated with $\mathrm{ZnO}$ flux powder

Fig. 8 Fracture surface of specimens at 200 magnifications.

\subsection{Effect of activating flux on interfacial reaction layers}

Yagati et al. (2014) revealed that the thickness of IMC layer between Al alloy and steel is less than $10 \mu \mathrm{m}$, the interface between $\mathrm{Al}$ and steel is stable. During the brazing process, the thickness of IMC layer varied with heat input. 
When the thickness between 8 and $12 \mu \mathrm{m}$, the tensile strength of lap joint specimens could reach $220 \mathrm{MPa}$ (Dharmendra et al. 2011). Fig.9 shows the IMC layer of interface that the surface of steel coated with the four types of flux powder. The thickness of IMC layer that specimens coated with $\mathrm{SiO}_{2}$ flux powder is the thinnest and the average thickness of IMC layer is approximately $6.45 \mu \mathrm{m}$, as shown in Fig.9c. On the contrary, the average thickness of IMC layer that specimens coated with $\mathrm{ZnO}$ flux powder is the thickest and the average thickness of IMC layer is approximately 14.62 $\mu \mathrm{m}$, as shown in Fig.9d. Qin et al. (2017) demonstrated that $\mathrm{Zn}$ is avoided to be directly heated by arc and the evaporation of $\mathrm{Zn}$ is decreased. Liquid filler Al alloy can spread on the surface well because the co-existence of $\mathrm{Zn}$ and activating flux powder. The flux and retained $\mathrm{Zn}$ facilitate the spread of filler metal on steel, which greatly improves its spreadability. However, different proportions of $\mathrm{KAlF}_{4}$ and $\mathrm{K}_{3} \mathrm{AlF}_{6}$ are applied to display different spreadability of $\mathrm{Al}$ alloy on steel surface, which may produce different temperature between Al alloy and steel surface. Due to the highest process temperature area influenced by the arc heating, it could be affected by the arc leading to a thicker IMCs layer. In this study, the surface of galvanized steel sheet coating with $\mathrm{CaF}_{2}, \mathrm{TiO}_{2}$ and $\mathrm{SiO}_{2}$ flux powder, the thicknesses of IMC layer are less than $10 \mu \mathrm{m}$. Due to the highest process temperature on the surface of base metal, the IMC layer of FZ presents a saw tooth shape, which may be influenced by the arc heating, as shown in Fig.9d. The results showed that the specimens produced by coating with $\mathrm{ZnO}$ flux powder may increase the temperature on the surface of galvanized steel sheet. It decreases the tensile strength of the $\mathrm{Al} /$ steel butt-joint specimens in this study.

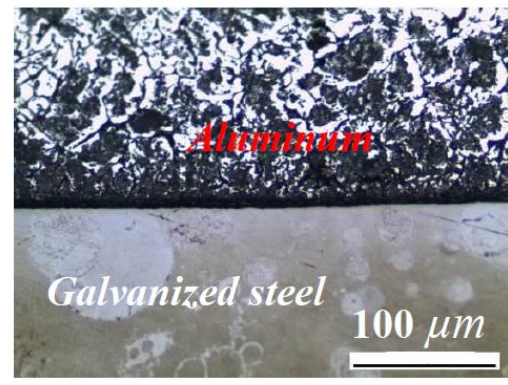

a. Coated with $\mathrm{CaF}_{2}$ flux powder

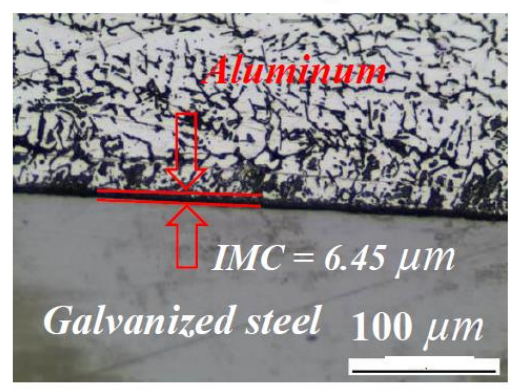

c. Coated with $\mathrm{SiO}_{2}$ flux powder

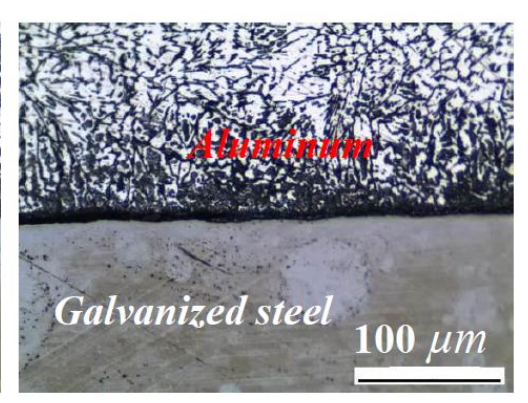

b. Coated with $\mathrm{TiO}_{2}$ flux powder

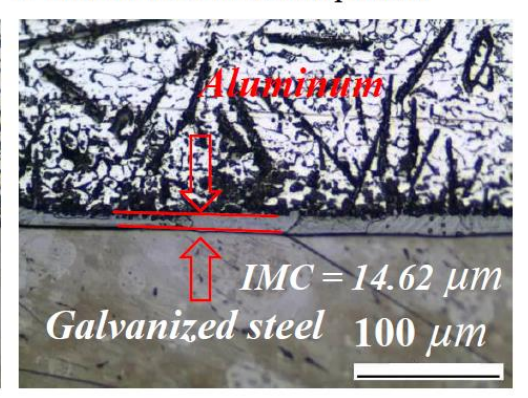

d. Coated with $\mathrm{ZnO}$ flux powder

Fig. 9 Effect of flux powder on weld-brazing interface.

\section{Conclusions}

During the MIG weld-brazing process for the Al/steel butt-joint specimens, four types of activating flux powder were selected to coat on the on the surface of galvanized steel sheet. The specific results are summarized as follow.

(1) The activating flux powder were coated with $0.3 \mathrm{~mm}$ thickness on the surface of galvanized steel sheet that increasing the heat input excessively, results in the appearances of weld bead are incomplete and numerous spatters. In order to obtain higher quality of butt-joint welds, the thickness of activating flux should be accurately control at $0.1 \mathrm{~mm}$ thickness.

(2) The $\mathrm{CaF}_{2}$ flux powder was applied as a suitable flux which the spreadability of filler material on galvanized steel sheet surface become better. When $\mathrm{SiO}_{2}$ flux powder was coated, the grains of FZ were coarser than other activating fluxes. However, the surface of galvanized steel sheets coated with $\mathrm{SiO}_{2}$ flux powder, the butt-joint specimen has the highest tensile strength. The average tensile strength of dissimilar materials butt-joint specimens is $160.6 \mathrm{MPa}$.

(3) When the $\mathrm{CaF}_{2}$ or $\mathrm{SiO}_{2}$ flux powder was coated, the higher heat inputs cause efficient escape of $\mathrm{Zn}$-vapor from the 
molten bead deposit, which decreases the amount of porosity in the FZ. It improves the tensile strength of the $\mathrm{Al} /$ steel butt-joint specimens.

(4) When the $\mathrm{CaF}_{2}, \mathrm{TiO}_{2}$ or $\mathrm{SiO}_{2}$ flux powder was coated, the thicknesses of IMC layer were less than $10 \mu \mathrm{m}$. However, the specimens produced by coating with $\mathrm{ZnO}$ flux powder may increase the temperature of FZ, the thickness of IMC layer was about $14.62 \mu \mathrm{m}$ and the IMC layer presents a saw tooth shape.

\section{References}

Basak S., Das H., Pal T.K. and Shome M., 'Characterization of intermetallics in aluminum to zinc coated interstitial free steel joining by pulsed MIG brazing for automotive application', Materials Characterization, (2016), Vol.112, pp. 229-237.

Chen S., Zhang J., Wang D., Wang J. and Li R., 'Study on low axial load friction stir lap joining of 6061-T6 and Zinccoated steel', Metallurgical and materials transaction A, (2019), Vol.50, pp.4642-4651.

Dharmendra C., Rao K.P., Wilden J. and Reich S., 'Study on laser welding-brazing of zinc coated steel to aluminum alloy with a zinc based filler', Materials Science and Engineering A, (2011), Vol.528, pp.1497-1503.

Dong H.G., Chen S., Song Y., Guo X., Zhang X.S. and Sun Z.Y., 'Refilled friction stir spot welding of aluminum alloy to galvanized steel sheets', Materials and Design, (2016), Vol.96, pp.457-466.

Dong H., Hu W., Duan Y., Wang X. and Dong C., 'Dissimilar metal joining of aluminum alloy to galvanized steel with Al-Si, Al-Cu, Al-Si-Cu and Zn-Cu filler wires', Journal of Materials Processing Technology, (2012), Vol.212, pp. 458-464.

Goecke S.F., Makwana P., Shome M. and De A., 'Probing joint strength and distortion in gas metal arc lap joining of aluminum and steel sheets', Welding in the World, (2019), Vol.63, pp.229-236.

Huang Y., Fan D. and Fan Q., 'Study of mechanism of activating flux increasing weld penetration of AC A-TIG welding for aluminum alloy', Frontiers of Mechanical Engineering in China, (2007), Vol.2, No.4, pp.442-447.

Lin H.L., Lee C.H., Chen H.Y. and Nan F.J., 'Effects of the MIG weld-brazing parameter on the lap-joint performance of aluminum alloy to galvanized steel sheet', Proceedings of the 2018 IEEE International Conference on Advanced Manufacturing, (2018), pp.40-43.

Lin H.L., 'Applying gray fuzzy logic to decide the weight ratio of activating flux during activated MIG aluminum alloy butt-joint welding', The International Journal of Advanced Manufacturing Technology, (2017), Vol.92, pp.471-479.

Lin H.L. and Yan J. C., 'Optimization of weld bead geometry in the activated GMA welding process via a grey-based Taguchi method', Journal of Mechanical Science and Technology, (2014), Vol.28, No.8, pp.3249-3254.

Lin Q.L., Mao G.J., Huang Q., Cao R. and Chen J.H., 'Effect of Zn vaporization on wetting of Al-galvanized steel in cold metal transfer process. Journal of Iron and Steel Research', International, (2016), Vol.23, No.6, pp.566-572.

Lü J.X., Yang W.X., Wu S.K., Zhao X.D. and Xiao R.X., 'Microstructure and mechanical properties of galvanized steel/AA6061 joints by laser fusion brazing welding', Acta Metallurgica Sinica (English Letters), (2018), Vol.27, No.4, pp.670-676.

Qin G., Ji Y., Ma H. and Ao Z., 'Effect of modified flux on MIG arc brazing-fusion welding of aluminum alloy to steel butt joint', Journal of Materials Processing Technology, (2017), Vol. 245, pp.115-121.

Ruan Y., Qiu X.M., Gong W.B., Sun D.Q. and Li Y.P., 'Mechanical properties and microstructures of 6082-T6 joint welded by twin wire metal inert gas arc welding with the SiO2 flux', Materials and Design, (2012), Vol. 35, pp.2024.

Shao L., Shi Y., Huang J.K. and Wu S.J., 'Effect of joining parameters on microstructure of dissimilar metal joints between aluminum and galvanized steel', Materials and Design, (2015), Vol.66, pp.453-458.

Ye Z., Huang J., Cheng Z., Gao W., Zhang Y., 'Chen S. and Yang J., Combined effects of MIG and TIG arcs on weld appearance and interface properties in $\mathrm{Al}$ /steel double-sided butt welding-brazing', Journal of Materials Processing Technology, (2017), Vol.250, pp.25-34.

Yagati K.P., Bathe R.N., Rajulapati K.V., Rao K.B.S. and Padmanabham G., 'Fluxless arc weld-brazing of aluminum alloy to steel', Journal of Materials Processing Technology, (2014), Vol. 214, pp.2949-2959.

Zhang M.J., Chen G.Y., Zhang Y. and Wu K.R., 'Research on microstructure and mechanical properties of laser keyhole welding-brazing of automotive galvanized steel to aluminum alloy', Materials and Design, (2013), Vol. 45, pp.2430 . 